\title{
Zdeněk Fibich's Missa brevis in F Major op. 21 in the Context of Czech Liturgical Compositions of the $1870 s-1880 s^{1}$
}

\section{Eva Vičarová}

\section{Introduction}

The Missa brevis in F Major op. 21 is a specific part of Fibich's compositional legacy. Apart from several instructive compositions, this mass cycle is the only composition created by the author in the period 1884-1885, when he had to cope with disappointment from negative reactions to the première of The Bride of Messina that took place in the National Theatre on 18 November 1883. His Missa was published soon after by Urbánek and was performed many times in Bohemian and Moravian churches. It remained part of the repertory up until the 1940s. Its compositional style reflects contemporary trends in composing. The following paper evaluates the piece and classifies it within the context of Czech as well as European liturgical art of the 1870s-1880s.

\section{Zdeněk Fibich and Liturgical Compositions}

The topic-based catalogue of Zdeněk Fibich's compositions, created by Vladimír Hudec, contains 21 liturgical compositions, which is a significant number in the context of the total of 655 recorded compositions (both finished and unfinished). ${ }^{2}$

1 This study received financial support from the Ministry of Education, Youth and Sports of the Czech Republic as part of the Institutional Development Plan granted to Palacký University Olomouc Faculty of Arts in 2020.

2 Vladimír Hudec, Zdeněk Fibich. Tematický katalog [Thematic Catalogue] (Prague: Editio Bärenreiter, 2001). An older catalogue, created by Jaroslava Javůrková based on five sources (V. Moser, C. L. Richter, F. A. Urbánek, O. Hostinský, and Z. Nejedlý), lists as many as 29 liturgical compositions. For more information, see: Artuš Rektorys, Zdeněk Fibich. Sborník dokumentů a studii o jeho životě a díle [Zdeněk Fibich: A catalogue of documents and studies concerning his life and work] (Vol. 2, Prague: Orbis, 1952).

This study uses catalogue numbers and data from Hudec's catalogue, although the majority of information and incipits are taken from Moser's catalogue. For more information, see Viktor Roman Moser, Tematický seznam veškerých skladeb Zdeňka Fibicha od r. 1862 do 31 . kvétna 1885 [Thematic Catalogue of All Compositions by Zdeněk Fibich from 1862 to 31 May 1885], manuscript, 
These compositions were created between 1862 and 1886, i.e. in different stages of the composer's personal and creative life. Unfortunately, Fibich destroyed most of his liturgical compositions in 1897 when he reviewed his compositional legacy. The only compositions preserved to this day are the already-mentioned Missa brevis in F Major Hud 279 and Psalm 64 Hud 255 in manuscripts and several incipits. ${ }^{4}$

The focus at this point will be on Fibich's compositional activities in the genre of sacred music in greater detail. ${ }^{5}$ His first opus of this kind is the Pange Lingua for mixed choir Hud 1. The future composer wrote this composition at the age of twelve, encouraged by Pater František Černý (1822-1884), the parson of the local church in Nasavrky and the prime mover of local cultural activities. ${ }^{6}$ In the following year, Fibich continued composing vocal compositions for liturgical texts; he apparently intended them to be performed as part of the liturgy in the Nasavrky church. He created the Mass in E Major Hud 176 in March 1863, followed apparently by five more pieces for mixed choir: Komm, Heiliger Geist Hud 801, Christi Mutter Hud 802, Segne Jesu Deine Herde Hud 803, Komm', O Fromme Hud 804, and Grosser Gott Hud 805.7

Several four-voiced choral pieces were composed by Fibich during his studies in Leipzig: Grosser Gott, Wir Loben Dich Hud 818, and Kyrie Hud 828 were composed in 1866, followed by the chorales Vom Himmel Hoch Hud 856, and Mache Meinen Geist Bereit Hud 857 in 1867. While living in Paris, Fibich wrote Ave Maria Hud 869 for tenor with piano accompaniment in 1868 and subsequently returned to the same prayer once again in Prague in 1873 (Hud 908).

176 pages, deposited with Fibich's family, and Tematický katalog veškerých skladeb Zdeňka Fibicha. Díl druhý 31. květnem počinaje [Thematic Catalogue of All Compositions by Zdeněk Fibich. Volume 2 from 31 May onwards], manuscript, unpaginated, deposited with Fibich's family. It is important to emphasize that the majority of the above-mentioned pieces are listed in the section of 'uncertain attributions' because they have not been preserved and information related to them is only mediated.

3 These were 204 of his mostly early pieces of music. - See Vladimír Hudec, Zdeněk Fibich (Prague: SPN, 1971), 19.

4 The manuscripts are preserved in the National Museum, the Czech Museum of Music, the Department of Music History, Missa brevis in F Major, part Benedictus, S80/115a, part Agnus and Dona, S80/115b, and Psalm 64, S80/116.

5 Sacred music is an umbrella term or synonym for Church Music / Sacred Music / Religious Music (German analogy: Kirchenmusik / geistliche Musik / religiöse Musik). The current text views sacred music as religious music composed for a liturgy or concert. Liturgical music is, in contrast, composed exclusively for a mass or non-mass liturgy. For a detailed definition of Czech musicological terms, see Jiř́ Fukač, “církevní hudba”, "chrámová hudba”, “duchovní hudba.” in Slooník české hudebni kultury [Dictionary of Czech Musical Culture], ed. Jiří Fukač, Jiří Vysloužil, Petr Macek (Prague: Editio Supraphon, 1997), 98-99, 170.

6 Hudec, Zdeněk Fibich 1971, 9.

7 Uncertain attributions, see note 2. 
It is uncertain whether these compositions were created out of a certain inner motivation or were a reaction to the demands of a local church, or possibly served educational purposes.

One might ask about Zdeněk Fibich's relationship to religion, the Christian faith, etc. There is no evidence indicating that one should think of $Z$ deněk Fibich as a "religious" composer similar to Anton Bruckner or Antonín Dvořák, who adopted the Catholic faith as their lifestyle and their relationship to God as the primary meaning of life. Although Fibich had experience with the church environment from childhood, he is more representative of the cultural-historical stream of composers who used religious texts and symbols to express general spiritual principles and values or personal emotions.

Purely tragic circumstances, for example, gave rise to two compositions created in Vilnius in 1874: the Requeim Hud 505, which unfortunately remained unfinished, was composed by Fibich after the death of his children, and this event was apparently also the motivation for a six-voiced motet Hud 909. In contrast, two smaller compositions, created towards the end of 1877, are of rather minor importance in the context of Fibich's compositions - these are the hymn Spirito Di Dio Hud 224 and a chorale for mixed voices Mache Meinen Geist Bereit Hud 918.

A significant stimulus for the composition of sacred music emerged in Fibich's life in 1878. In October, the composer replaced his colleague Karel Bendl in the office of choirmaster of the Prague Orthodox church and remained there for three years. Composing sacred music was part of Fibich's new position. His first compositions were created as early as Christmas 1878: Weihnachtslied Hud 244, a cyclical chorale composition to Martin Luther's text, the Sonata in B Flat Major for organ Hud 245, ${ }^{8}$ and the six-voiced a cappella Ave Maria Hud 925. One year later, he composed the three-voiced a cappella canon Aleluja Hud 923 and Psalm 64 Hud 255 with a German text for mixed choir. The gloomy text of the last-mentioned composition - "God, hear thou my prayer, when I beseech thee; save thou me from the threats of my enemies."- suggests that its words were used by Fibich to cope with a certain personal hardship. They may have been related to the typhoid disease which afflicted the composer and his family at that time. ${ }^{9}$ Alternatively, he may have taken inspiration from Antonín Dvořák and his contemporary composition of Psalm 149.

Apparently for a Catholic church, since organs are not part of Orthodox churches.

9 For more information, see: Kristýna Štiaková, “Sociální postavení Betty Fibichové (roz. Hanušové) a Zdeňka Fibicha v letech 1874-1885 [The social status of Zdeněk and Betty Fibich in the years 1874-1885]" (Bachelor thesis, Palacký University Olomouc, 2020), 50, 53.

For a translation of the biblical text the "Wycliffe Bible" was used, accessed 15 December 2020, https://www.biblegateway.com/versions/Wycliffe-Bible-WYC/\#copy. 
Fibich focused on sacred music for the last time in the mid-1880s. He composed the Missa brevis in F Major in May 1885. The last Kyrie Hud 285 was inscribed by Fibich with the date 4 March 1886 . He subsequently never composed any other sacred music.

In terms of the musical characteristics of the above-listed pieces, only general hypotheses are available. Fibich's liturgical compositions undoubtedly reflected practical experience gained by the author in his engagements as a choirmaster and conductor. Prior to his three-year period as the master of the Prague Orthodox church ensemble, Fibich worked as a teacher of choral singing in Vilnius (1873-1874), where his workload consisted of fourteen lessons of choral singing at five different schools, and as assistant conductor and choirmaster of the Prague Provisional Theatre (1875-1878). Fibich was undoubtedly acquainted with a number of historical and contemporary vocal musical compositions. In documents addressed to the Prague Municipal Council dated 4 May 1878, where he applied for the office of the master of the church ensemble, he described himself as a "devout admirer of classical and sacred music." ${ }^{10}$ This was also confirmed by O. Hostinský, who allegedly discussed selected passages from his Dějiny budby [History of Music] with Fibich. ${ }^{11}$ Scores preserved in Fibich's library included great sacred musical pieces by composers from the Baroque, Classical, and Romantic periods, as well as Renaissance vocal a cappella polyphonic works (masses by Palestrina and Lassus). ${ }^{12}$

In light of the fact that the time span between Fibich's first and last liturgical compositions is 23 years, it is apparent that Fibich's compositional style developed from early juvenile attempts and reflected the author's increasing compositional erudition and creative originality. This can be seen from the musical language of Fibich's mass cycles. Fibich made an attempt at writing a mass five times: the first one, the Mass in E Major, was composed at the age of thirteen, and the only information we have about it is that it was composed for solo voices and mixed choir with accompaniment. It was a short composition with a total of 607 bars (Kyrie, 30 bars; Gloria, 162 bars; Credo, 267 bars; Sanctus, 41 bars; Benedictus, 43 bars; and Agnus Dei, 28 bars).$^{13}$ The preserved incipits provide us with valuable pieces of information. The organ accompaniment is homophonic with prevalent broken-chord figures and traditional classical-period harmony. The composition apparently represented contemporary figural music. Another Kyrie was composed by Fibich in Leipzig in 1866. Unfortunately, neither the composition nor its incipit has been preserved. Fibich's intention, when com-

\footnotetext{
${ }^{10}$ Hudec, Zdeněk Fibich 1971, 46.

${ }^{11}$ Hudec, Zdeněk Fibich 1971, 46, 48.

12 Rektorys, Zdeněk Fibich, 331-343.

13 Hudec, Thematic Catalogue, 224-225.
} 
posing a Requiem (1874), was apparently to create a magnificent composition, because apart from solo and choral parts the ensemble also included an orchestral accompaniment. We will unfortunately never know the reason why Fibich left the composition unfinished after 91 bars. The incipit, consisting of only three bars, includes arpeggio chords evoking a dramatic atmosphere. ${ }^{14}$ The Missa brevis in F Major will be addressed in the following section. The last four-voiced Kyrie is inscribed with the date 4 March 1886. As is obvious already from the incipit of the first five bars, the mass was designed as a polyphonic a cappella composition - the tenor line develops as a strict imitation of the bass. ${ }^{15}$

\section{Liturgical and Sacred Repertory in the Czech Lands in the 1870s-1880s}

The following section will address the repertory and liturgical compositions typical for the Czech Lands in the 1870s and 1880s in order to provide the background for Fibich's compositional style.

Czech churches at this time echoed with two types of compositions. The first one followed the tradition of the extremely popular figural music of the day, while the second one reacted to the Cyrillian church music reform movement which was in its most intense stage in the Czech Lands at the time Fibich was composing his mass. It is important, however, to realize that as a result of the inhibition of religious faith and due to its utilitarian nature, contemporary composing of liturgical music was gradually losing its prestige in intellectual circles, and sacred music created primarily for concert performance was generally appreciated more. In Western Europe, this line was represented by compositions by Ch. Gounod, C. Franck, and C. Saint-Saëns; in Czech musical culture, compositions by Antonín Dvořák (Svatebni košile [The Spectre's Bride], 1885, Svatá Ludmila [Saint Ludmila], 1886, and the Requiem, 1890) were paramount.

Both types of contemporary church music in the Czech Lands will now be characterized in greater detail. Figural music was performed on all ceremonial and representational liturgical occasions. It encompasses compositions with the accompaniment of bowed and wind instruments and an organ whose musical language followed the principles established by the Baroque and Classical-period authors. The compositions were designed for soloists, a choir, and an orchestra. The form of the individual parts of the mass ordinary was based on the text. The Kyrie had a three-part form set by the threefold address Kyrie, Christe, Kyrie. The Gloria was also divided into three parts, the second of which began with the words Qui tollis, and the third with Quoniam tu. The parts of the Credo

${ }_{14}$ Hudec, Thematic Catalogue, 505.

15 Hudec, Thematic Catalogue, 337. 
'illustrated' epic passages from the confession of faith; in the Austrian tradition, the word Credo was also inserted within the other individual parts. The Sanctus had a two-part form, the second part beginning with the word Hosanna. The two-part Benedictus, with the second part again starting with Hosanna, was followed by the three-part Agnus Dei, whose first and second parts finished with Miserere nobis, and whose third part closed with Dona nobis pacem. The melody of the Kyrie was only repeated occasionally in the Agnus Dei; apart from the Kyrie, all the parts ended with a fugato. In some cases, the fugato at the end of the Sanctus and Benedictus was identical. The harmonic-melodic structure was based on Classical-period principles. The texture was prevalently homophonic but some passages, particularly the ends of the individual passages of the ordinary, were polyphonic. The rhythm was based on the text. The passages of the words with the most important content were usually arranged as unisono. Interval combinations naturally enhanced the expressivity of the words: for instance, the word Crucifixus was written as a unisono for deep voices and accompanied as a funeral march. While the phrase sepultus est was rendered at a piano dynamic level, Ressurexit was performed tutti forte. Compositions by Czech authors were generally characterised by remarkable melodic inventiveness and a rather simple contrapuntal form.

The authors whose music was performed in the Czech Lands included the following non-native composers: the Haydn brothers and Beethoven, as well as Johann Georg Albrechtsberger (1736-1804), Anton Diabelli (1781-1858), Johann Nepomuk Hummel (1778-1837), Luigi Maria Cherubini (1760-1842), Friedrich Kempter (1810-1871), Johann Baptist Schiedermayer (1779-1840), and Josef Ignaz Schnabel (1767-1831). Frequently performed domestic authors included Václav Jan Tomášek (1774-1850), Jan Augustin Vitásek (1770-1839) and Bedřich Diviš Weber (1766-1842), later Alois Hnilička (1826-1909), Zikmund Kolešovský (1817-1868), and Jan Nepomuk Škroup (1811-1892). Czech cantors, whose compositions were frequently performed, included Karel Bořický (1789-1861), František Doubravský (1790-1867), Jan Nepomuk Filcík (1785-1837), František Kadleček (1781-1874), František Václav Karlík (1811-1889), Jan Kypta (1813-1868) and Jakub Jan Ryba (1765-1815). The most popular domestic authors were, however, the regenschori from St. Vitus Cathedral and organist Robert Jan Nepomuk Führer (1807-1861), and the bandmaster from the St. Vojtech Church and Tyn Church Václav Emanuel Horák (1800-1871).

As a reaction to this compositional style, which was not all that different from contemporary secular music, the Czech Lands were visited by the European reform movement in the 1870s - the Cecilian Movement. Its aim was to 'cleanse' 
music from secular fouling. In the Czech Lands, the revivalist movement striving for the reinstatement of Gregorian chant and Renaissance vocal polyphonic compositions in church music was named after St. Cyril - "Cyrillismus" [the Cyril Movement]. ${ }^{16}$ In 1874, a priest and teacher of choral singing in a seminary, Ferdinand Lehner, established the journal Cecilie (1874, from 1879 renamed Cyril); a few years later, he established Obecná jednota cyrilská [the General Cyrillic Unity] (1879). The institution attracted all the supporters of church music reform, especially from the circles of choirmasters, and the journal was intended, among other things, to provide them with an appropriate repertory.

The ideals of the Cyril Movement were enforced in the Czech Lands in several stages. A typical feature of the 1870s is a fundamentalist approach to the performed repertory. Cyrillists eradicated all musical instruments from churches apart from the organ, and returned to the compositions of the Renaissance masters. Another type of music that was deemed acceptable was that by contemporary German composers who observed the principles of a cappella vocal polyphony, such as Heinrich Oberhoffer (1824-1885), Johann Gustave Eduard Stehl (1839-1915) and Franz Xaver Witt (1834-1888). There were three esteemed Czech composers: František Zdeněk Skuherský (1830-1892) - director of the Prague organ school and regenschori of St. Catullus Church (1868-1872) and of the Church of the Holy Trinity on Spálená street (1872-1891), Josef Förster (1833-1907) ${ }^{17}$ - choirmaster of St. Vojtech Church (1863-1888) and later of St. Vitus Cathedral (1887-1907) and professor at the Prague Conservatory, and Pavel Křížkovský (1820-1885) - an Augustinian monk and choirmaster in Staré Brno (1848-1885) and in Olomouc (1872-1883).

Compositions of renowned contemporary German and Czech authors had the following features: they were based on a polyphonic approach but the most fundamental passages of the text of the mass ordinary were arranged as syrrhythmic or unisono homophony. The form of the individual parts of the ordinary

${ }_{16}$ The Cecilian Movement was a purist reform movement established in the early 1800s in Germany striving for a "cleansing" of liturgical music from secular elements. Cecilianists systematically returned to Gregorian chant and Renaissance vocal polyphony, but also tolerated contemporary compositions based on these musical styles. They promoted a cappella ensembles or organ accompaniment and, in contrast, rejected figural music. The greatest promoters of church music reform in Germany were the Protestant theologian Anton Friedrich Justus Thibaut, Carl Proske, a canon of Regensburg cathedral, and Franz Xaver Witt, a priest and author of 51 ,muster masses. Cecilianism found support even among top-rank composers, e.g. Franz Liszt (one might mention his Missa Choralis) and Anton Bruckner (Mass in E Minor) were some of its promoters. For more information, see Siegfried Gmeinwieser, "Cecilian Movement" in The New Grove Dictionary of Music and Musicians, vol. 5, ed. Stanley Sadie, John Tyrrell (New York: Grove, 2001), 333-334.

17 The treatise consistently uses the commonly used German transcription of the name Josef Förster for the father, and the Czech transcription of the name Josef Bohuslav Foerster for the son. 
was based on the text and its semantic units. The meaning of the text was also emphasized with musical rhetoric figures. Although some melodic passages were sometimes repeated - the motif of the Kyrie also appeared, for example in the Agnus Dei - in general each part of the mass cycle proceeded as a flow of polyphonic passages with a prevalence of evolutional music. The composers frequently used the motet technique: a melody exposed in one vocal part was subsequently imitated in the others and ended with a cadence. Following the cadence, however, the melodic line was not finished - there was either a new motif initiated by another vocal line, subsequently followed by the others, or the line was continued in the particular vocal part even following the cadence. The final part usually consisted of melismatic codas sung on the word Amen. The Renaissance spirit of these compositions was frequently enhanced by the utilization of the Venetianschool double-choir technique. The purpose of the organ accompaniment was practical: it provided singers with the necessary harmonic support.

Not every church choir, however, was able to perform complex contrapuntal compositions. In addition, many contemporary composers were not endowed with such inventiveness and technical expertise that would allow them to compete with the above-mentioned masters. As a result, there were a number of schematic and eclectic works that would not otherwise succeed. Such compositions were characterized by unimaginative melodies, a homophonic texture including only hints of polyphony, and uncomplicated harmony; their organ accompaniment frequently resembled basso continuo. These compositions nevertheless fulfilled their short-term or utilitarian purpose.

The Cyril Movement was not accepted without controversy and reservations, both from representatives of the church and from the community of believers. The pseudo-renaissance music with an ascetic sound stood in sharp contrast with the 'lively' spirit of figural music hitherto used by the church for spectacular representation. For this reason, many church ensembles remained entirely unaffected by the Cyrillian reform.

Discussions regarding the contemporary form of liturgical music understandably filled the pages of the music journals of the day, such as Ceskoslovensky varhanik [Czechoslovak Organist], Dalibor, and Novy život [New Life] in the 1880s. There was agreement as to the conviction that sacred music should be 'cleansed' from secular fouling and that it should retain its original dignity and seriousness. In addition, there was no doubt that particularly Gregorian chant and Renaissance vocal polyphony were most appropriate for such efforts. Mention should be made, for example, of the opinion stated by Bedřich Smetana, who believed that the most prominent authors contributing to the flourishing of church music were particularly Palestrina, Lassus, Allegri, etc. He expressed 
admiration for the way these old masters used all musical means to "fill the matter with spirit". ${ }^{18}$ Otakar Hostinský was also of the same view and wrote an article "Händel a Bach [Handel and Bach]", presenting the opinion that "the paramount of musical art, its greatest flourish and most dignified manifestation will always be polyphony". ${ }^{19}$

The most frequent argument by antagonists of the Cyril Movement was that as a result of their fundamentalist approach to the reform, the Cyrillists rejected grand historical artworks and that, most importantly, their new compositions failed to acknowledge the contemporary musical language. This attitude was advocated for instance by Leoš Janáček: "What is now - unfortunately - considered 'sacred music' is what nobody likes. Genuine composers are afraid to write with enthusiasm. Only sixth triads - scarcely a seventh one - that is the recipe for modern sacred compositions... We ask that the composers create sacred compositions inspired by religious sensation; the hearty sensation is what composers should be filled with, otherwise they create feeble melodies and harmonies." ${ }^{20}$

A treatise by F.Z. Skuherský O formách hudebnich [On Musical Forms] (1879) launched the second phase of the Cyril Movement emerging in the 1880s and 1890s. In the work, the author worships the perfection of Mozart's Requiem, as well as compositions by Bach, Händel, Haydn, Cherubini, and Beethoven, which resulted in the return of these masters to reformed church ensembles. Another important feature was that the new compositions gradually began to incorporate contemporary compositional language. The most successful composers combining the technique of vocal polyphony with modern harmony were regenschori of the Mladá Boleslav church ensemble František Hruška (1847-1889) and his successor Josef Cyril Sychra (1859-1935), the regenschori of Olomouc cathedral Josef Nešvera (1842-1914), and the choirmaster of St. Ursula Church, the prominent teacher and theorist Karel Stecker (1861-1918).

Zdeněk Fibich undoubtedly knew what kind of repertory was being played in Czech churches and was acquainted with the compositional trends of contemporary liturgical music. He contributed to Dalibor with his reflections on contemporary musical life, so he undoubtedly knew about the reports and polemics published in this and other music journals. He approached liturgical and sacred music as an autonomous area of composition which was deserving of the

${ }_{18}$ Josef Srb-Debrnov, "Missa solemnis. Složil Josef Čapek v Götteborku r. 1860. Ze zápisků Smetanových podává J. Debrnov [Missa solemnis. Created by Josef Čapek in Gothenburg in 1860. From Smetana's notes, presented by J. Debrnov]", Dalibor 23, 1901, no. 31 (27 July 1901): 245.

19 Otakar Hostinský, "Händel a Bach [Handel and Bach]", Dalibor 7, 1885, no. 4 (14 April 1885): 132.

${ }^{20}$ Leoš Janáček, Hudební listy [Musical Journal], (1 February 1887): 69-70. See also Rektorys, Zdeněk Fibich, 304-305. 
attention of composers as much as any other musical genre. Liturgical music was composed by other representatives of Fibich's generation as well: Vilém Blodek wrote two masses in the 1860s, Karel Kovarovic composed several sacred choral compositions in the late 1870s, and Josef Klička began composing mass cycles at the beginning of the 1880s.

There is no doubt that Fibich was aware of the works of his fellow composers. His greatest idol Bedřich Smetana, however, did not compose sacred music and apart from several choral compositions with religious texts from the 1840s did not contribute in any way to this musical genre. As for Antonín Dvořák, his greatest liturgical compositions, including the Mass in D Major "Lužanská" (1887 / 92), were yet to be composed. Fibich could have also attended the Prague premières of Psalm 149 (1879) and Stabat Mater (1880), and certainly knew about Dvořák's successful performance of this oratorio in London (1884) and could even have possibly known several smaller liturgical compositions composed by Dvořák at the end of the 1870s and published by E. Starý in 1883. These are compositions for one or two vocal parts with organ accompaniment sung to the Latin texts Ave Maria, O Sanctissima and Ave Maris Stella. Karel Bendl was a friend of Fibich, Fibich having replaced him as conductor of the Provisional Theatre and the Orthodox church. Fibich therefore knew his Missa Solemnis from the year 1870 as well as his Missa Vocalis for four vocal parts a cappella (1873). Fibich was also in close contact with the main figure of the Cyril Movement František Zdeněk Skuherský. This is documented for instance in a letter from 20 May 1885, where Skuherský thanks Fibich for a professional disputation. ${ }^{21}$ Fibich therefore could have been acquainted with, for instance, his Missa brevis op. 47 (1880). As concerns Fibich's contemporaries, liturgical music was also composed by Leoš Janáček, a graduate of Skuherskýs organist school. His works from the 1870s (graduals, an introit and prayers) were nevertheless only performed in Brno and not published.

\section{Missa brevis in F major}

\section{a) Historical Background of the Composition, Its Reception and Reflections on It}

As has already been mentioned, this mass cycle has a special place among Fibich's compositions. The period of its creation was very difficult for the composer: he was dealing with a crisis resulting from his own innovativeness in the genre of opera. His progressive musical language remained misunderstood. It was perhaps for this reason that the composer decided to take a break from composing and

${ }^{21}$ Rektorys, Zdeněk Fibich, 495. 
in 1884-1885 focused his attention only on instructive piano compositions and the above-mentioned mass. The first composition on a larger scale following this period of stagnation was the overture to the comedy Noc na Karlstejně [A Night at Karlstein] (1886).

The Missa brevis belongs to a period that was described by J. Jiránek as "supreme romantic innovation in form" and which gave rise, apart from the above-mentioned opera, to a number of songs, piano and chamber-ensemble compositions, as well as the symphonic picture Vesna [Spring] (1881), the cantata Jarni romance [Spring Romance] (1881), the melodramas Vodnik [The Watersprite] (1883) and Královna Ema [Queen Emma] (1883) and the 1st Symphony in F Major (1883). ${ }^{22}$

Is it possible that the mass served Fibich as a means to unwind during this tough period? Or did the traditional compositional style help him to find a creative balance? Did the work on the Missa brevis evoke the time of his carefree childhood and bring back memories of happy years spent with his parents at Libáň? Or did the author express here his fondness for one particular parson and decide to dedicate a composition to him? There is no way of answering these questions with certainty at present, so let us stick to the facts.

The Missa brevis is the only published liturgical composition written by Fibich. It is arranged for a mixed choir accompanied by organ and a string orchestra (ad lib). As concerns its name, the mass is labelled "brevis" because it is rather short and simple, not because it would lack some passage of the mass ordinary, as sometimes occurred with other such compositions. The author dedicated the composition to Pater Valentin Bečvář, parson and dean of St. Giles Church in Moravské Budějovice. The town was the birthplace of the composer's publisher and friend, whom Fibich visited at the turn of September 1884 on the occasion of the opening of the local kindergarten. ${ }^{23}$ A concert of Fibich's compositions was also organized. Fibich began composing the mass on 25 May 1885 and worked on it for one month. It was published on 24 November 1885 by Urbánek in Prague. Hudec's catalogue states that the first performance took place in Lviv on 20 January 1886, conducted by Břetislav Lvovský. ${ }^{24}$

The composition was performed quite frequently. For instance, in JanuaryMarch 1886 alone it was performed, apart from in Lviv, also in Prague cathedral and in Moravské Budějovice, Hradec Králové and in the Prague Old

\footnotetext{
${ }^{22}$ Jaroslav Jiránek called this period the crisis and the new rise. The crisis, resulting from the reception of The Bride of Messina, was overcome by the composer by composing concert melodramas. For more detail, see Jaroslav Jiránek, Zdeněk Fibich (Prague: Akademie múzických umění, 2000), 168.

${ }^{23}$ On a visit to Moravské Budějovice see Rektorys, Zdeněk Fibich, 271-303.

${ }^{24}$ Hudec, Thematic Catalogue, 328.
} 
Town (at St. Catullus Church). It was subsequently even performed in other Bohemian and Moravian churches and remained in their repertory up until the 1940s. Reports published in the journal Cyril, reflecting on the activity of Parish Cyril Unities, document performances of the mass in Ústí nad Orlicí (1886, 1939), Mělník (1892), Veliš (1895), Kolín (1896), Rychnov nad Kněžnou (1903), Rakovník (1909, 1914), Rožnov pod Radhoštěm (1910), Prague Old Town (St. Catullus Church 1911, 1926, 1928), Prague-Dejvice (St. Matthew Church) (1911), Dobrovice (1912), Prague-Smíchov (St. Wenceslas Church, 1914), Domažlice (1915), Prague-Žižkov (1916, 1929), Tábor (1917), Prague Královské Vinohrady (St. Ludmila Church, 1917), Prague New Town (Church of Our Lady of the Snows, 1923), Prague - Lesser Town (1926), and Prague Old Town (St. James Church, 1940). ${ }^{25}$ The inventory of sheet music preserved in the Brno Minorite Monastery (Church of St. John) suggests that Fibich's mass was even performed here. ${ }^{26}$ It is natural that some choirmasters included the composition in their core repertory, so it was performed regularly and remained in the repertory of the choir even after the choirmaster's retirement, or the choirmaster took it to his next workplace. This was the case with Cyril Sychra and his successors in Ústí nad Orlicí, and Josef Winter, who worked in Kolín, Mladá Boleslav and Prague.

As concerns the reception of the composition, the first evaluations regarding the structure of the composition were positive. The January 1886 performance in Moravské Budějovice, conducted by E. Spatinka with Karel Förster (brother of Josef Förster) playing the organ, was regarded by Dalibor, for example, as "exceptionally successful" 27 and a review of its performance conducted by J. N. Maýr, which took place at the Prague Knights of the Cross on 2 March 1886, claims it gave "a fantastic impression" and received "enthusiastic" reactions. ${ }^{28}$ A similar reflection is also provided by a report in Dalibor taken from the daily Pokrok [Progress], where N. Krátký includes Fibich's mass among those sacred compositions whose "modern means do not disrupt listeners' pious mood and carry the true church spirit". ${ }^{29}$

A certain doubt as to the style of the composition with regard to the Cyrillian reform was first expressed by the reviewer Mazánek in the journal Dalibor in

${ }_{25}$ Based on excerpts of the Cyril music magazine from 1885 until 1948, accessed November 2020, http://cyril.sdh.cz/?a=14.

${ }_{26}$ Theodora Straková, Jiří Sehnal, Svatava Přibáňová, Prưvodce po archivnich fondech Ústavu dějn hudby Moravskébo musea v Brně [Guide to the archives of the Institute of Music History of the Moravian Museum in Brno] (Brno: 1971), 23.

${ }^{27}$ Dalibor 8, no. 1 (7.1.1886): 8

${ }^{28}$ Dalibor 8, no. 9 (7.3.1886): 89.

${ }^{29}$ Dalibor 8, no. 38 (14.10.1886): 378-379. 
October 1886. Fibich's mass was performed at the beginning of the school year in Ústí nad Orlicí on 16 September 1886 with a string orchestra but without organ accompaniment. The author of the review claimed among other things the following: "...it needs to be noted that the "Benedictus" and "Dona", as manifested in the performance, oppose the church style with their rather excessive sweetness, and do not reach in any way the qualities of the other parts (Kyrie, Gloria, Credo) against which even the greatest supporters of precise sacred music cannot have any reservations. Laymen might like these two particular parts the most; however, anyone who has learnt to differentiate to some extent between the church style and the style of modern secular compositions will undoubtedly say: while the "Benedictus" and "Dona" are beautiful, it is not pleasant to listen to them in a church...". ${ }^{30}$ Mazánek's summary is, however, conciliating. He adds that the objective of his criticism was not to discourage those in regenschori positions from "performing Fibich's mass; on the contrary, we propose performing it, since the remaining parts are very reverend indeed, and Fibich's mass outclasses all older compositions, such as Horák's masses, so performing it will amount to a great leap forward in the remediation of sacred music." ${ }^{31}$

In the pages of Hudebni listy [Musical Journal] in 1887, the composition was discussed by Leoš Janáček. His attitude to it was rather critical: in particular, he criticised the composition's lack of stylistic unity: "It proceeds without any poeticism (for instance in the Credo), and the individual sections lacking a uniform style are arranged into a whole without uniformity. For instance, the exposition 'cum sancto spiritu', arranged in semiquavers and quavers, is apparently justified merely by historical tradition: in the eighteenth and early nineteenth centuries, fugues had to occur at the end of the Kyrie, Gloria, Credo, Sanctus simply everywhere." ${ }^{2}$ Janáček also criticised the conservative harmony and poor melodic inventiveness: "Et incarnatus est, played on a single note g, documents the poor melody - we had hoped that it would at least be compensated for by a new, intriguing harmony, but it is not." 33 A comparison of Fibich's Missa brevis to contemporary German compositions was, however, quite positive for his composition: "Nevertheless, compared to similar compositions that come to us from Germany, Fibich's Missa is outstanding, and for this reason we recommend it to all choirmasters. The publisher Frant. Urbánek published it in a beautiful edition." 34

\footnotetext{
30 Ibid.

${ }^{31}$ Ibid.

${ }^{32}$ Leoš Janáček, Hudební listy [Musical Journal], (1 February 1887): 69-70. See also Rektorys, Zdeněk Fibich, 304-305.

33 Ibid.

${ }^{34}$ Ibid.
} 
In the context of Fibich's monography, the composition was assessed in 1901 by Zdeněk Nejedlý. He compared the composition with Liszt's works and praised Fibich as a skilled contrapuntal composer: "Even here, in the Credo, we can see a programmatic composer who is not afraid, led by the genius of his contrapuntal thinking, of presenting the principle of dramatic expression in sacred music (following the example of Liszt, who developed the Credo of his Mass of Esztergom in the entirely free form of a robust symphonic poem including a choir)." ${ }^{35}$ Nejedlý praised the composition's character as being very progressive: "Fibich's music, his spirit and works exceed and eclipse everything in such a way that St. Vitus Cathedral, the centre of all musical backwardness, shall fall on the heads of its servants, so that the mighty spirit of progress can rise in the power of true free art. Te confitemur!"36

The perception of Fibich's mass with a time span greater than half a century by Josef Cyril Sychra, a regenschori and composer, is obvious from the statement that the composition "did not particularly prove itself in the development of sacred music and did not influence it in any way". ${ }^{37}$ In his view, the value of the composition was doubtful, especially due to the lack of uniformity in the compositional style, which mixed elements of the purist movement with idioms of Baroque music which the Cyrillian reform fought against.

As is apparent, the reactions to the compositional style of Fibich's mass are considerably varied. Now, let us focus on its analysis.

\section{b) Analysis of Style}

The composition consists of 452 bars and comprises the following: Kyrie (42 bars), Gloria (71 bars), Credo (158 bars), Sanctus (51 bars), Benedictus (46 bars), Agnus (23 bars) and Dona nobis (51 bars).

All parts of the ordinary are divided into individual sub-sections contrasting with each other due to the use of homophony and polyphony. The Kyrie consists of three parts (Kyrie, Christe, Kyrie) extended by a thematic organ prelude and interlude. The Gloria may be divided into two large segments, the second of which starts with the words Cum sancto spiritu and proceeds as a fugue. The coda Amen is a chordal cadence. The Credo is in a three-part form, extended by a closing Amen. The Sanctus is divided into two parts, the second starting with Hosanna. This part also contains a four-bar coda. The Benedictus also consists

35 Zdeněk Nejedlý, Zdenko Fibich. zakladatel scénického melodramu [Zdenko Fibich. Founder of Scenic Melodrama] (Prague, own edition, 1901), 76. The review of the composition was apparently only based on the published score.

${ }^{36}$ Ibid.

37 Cyril Sychra, “Z pražských kůrů”, in Cyril 65, no. 8-10, (1939): s. 105. 
of two parts: the Hosanna and final coda are identical to the equivalent passages of the Sanctus. The Agnus is followed by the independent Dona nobis pacem.

The prevalent texture in both the vocal and instrumental elements of the mass is homophonic. The organ accompaniment oscillates between supporting the vocal lines (doubling the four-voiced writing) and creating an independent accompaniment in the form of instrumental preludes, interludes, colouring of vocal lines, etc. Another enriching aspect is the combination of the homophonic texture of the choir and the contrapuntal lines of the organ accompaniment. (Both possibilities in example 1)

The main starting-point in the choral texture is the four-voiced structure, switching between two-voiced and four-voiced passages with various vocal combinations. The male and female voices frequently stand in opposition to one other, further contrasted with tutti phrases which evoke an echo effect. The individual voices are mostly arranged in thirds and proceed either parallel to one other or in opposite directions. (Example 1)

In the passages with a four-voiced structure, each of the voices is arranged independently. This technique evokes a polyphonic texture. This tradition reached its peak in the choral compositions of the authors of modern Czech music, such as Pavel Křížovský, Bedřich Smetana, Antonín Dvořák, as well as Leoš Janáček and Josef Bohuslav Foerster.

As concerns the polyphonic texture, Fibich works both with the techniques of Renaissance vocal polyphony and with Baroque counterpoint. In general, however, his counterpoint is uncomplicated, based on the diatonic scale, usually only stretching over several bars and subsequently changing into homophony. (Example 1, bars 6-9) The most widely used technique is imitation at the fifth evoking fugato and the entry of voices dux (i.e. leading voice) and comes (i.e. trailing voice). (Example 1, bar 6) The Baroque atmosphere may also be noticed in the utilization of passing and neighbouring notes and appogiaturas in vocal lines as well as in the organ accompaniment. (Example 1)

Basso continuo is applied, for example, in the Credo (Example 2). The frequent alternation of harmonic functions, where almost every note of the leading vocal line is supported with a chord, is employed by Fibich to achieve an effect used for the harmonization of the Protestant chorale.

The tonal layout is rather simple. The first four parts are arranged in the main key F major; the Benedictus is in B flat major, but at the Hosanna the composition returns to the main key of the cycle and remains in it until its end. The two main keys of the entire cycle thus form a plagal cadence.

The secondary dominants on the subdominant and submediant are a remarkable element in the harmony. The modulations lead into a parallel scale. The plagal ending of some parts, for instance the Gloria and Credo, is rather exceptional. 

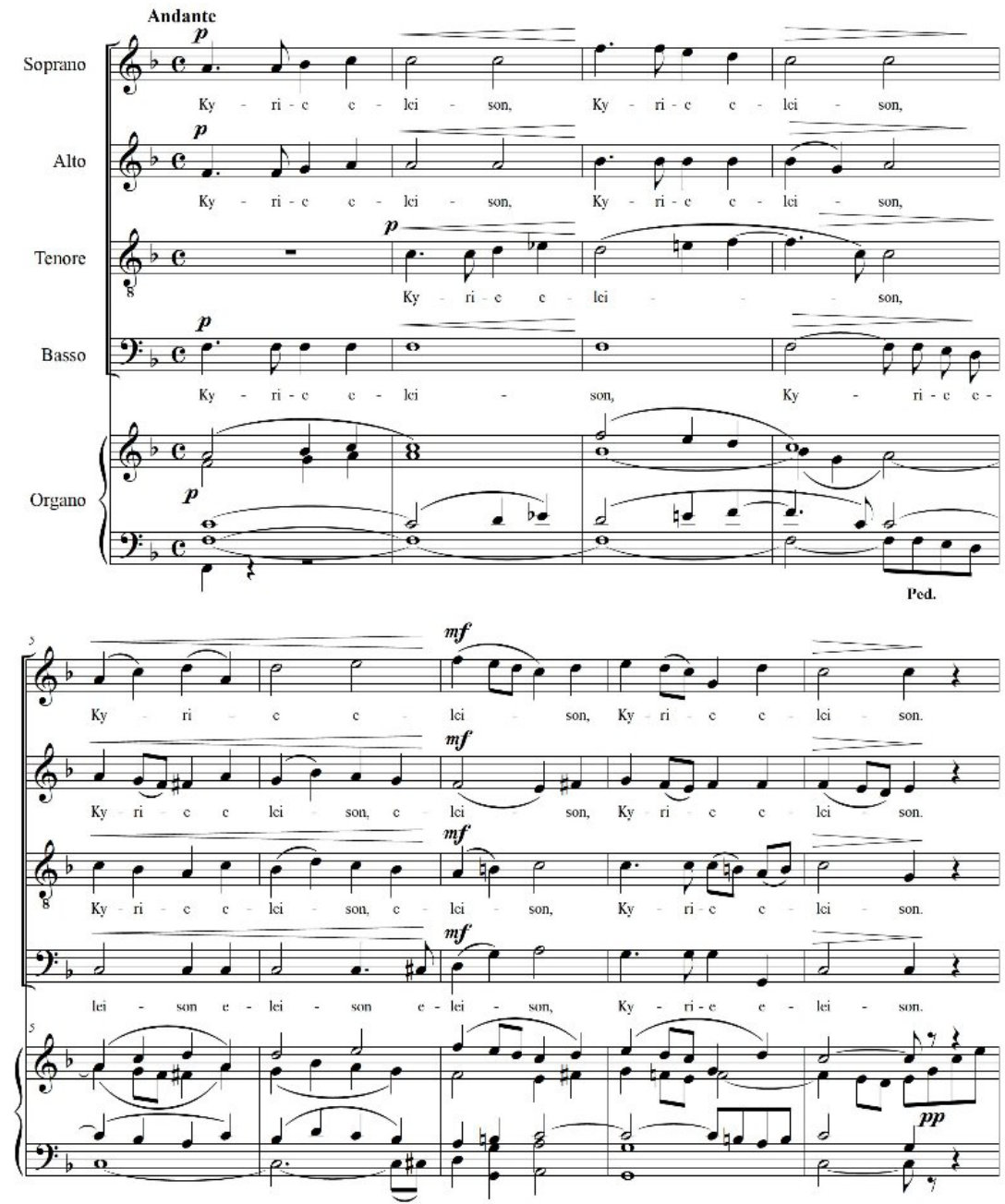

Example 1 Zdeněk Fibich, Missa brevis, op. 21, Kyrie, mm. 6-14 


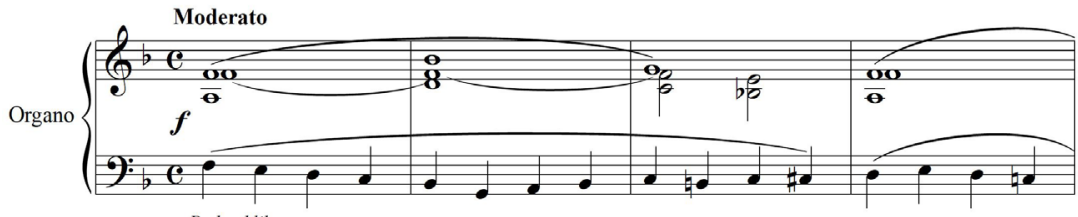

Ped. ad lib.

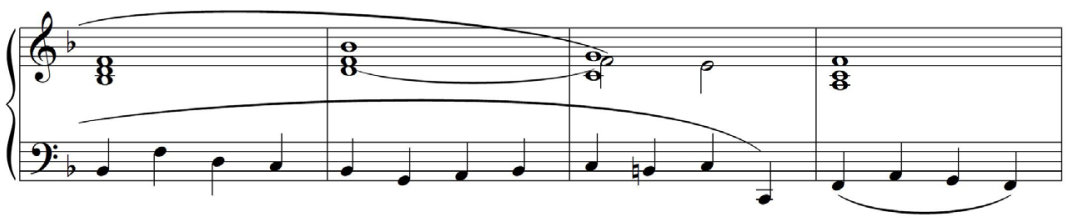

Example 2 Zdeněk Fibich, Missa brevis, op. 21, Credo, mm. 1-8 (organ)

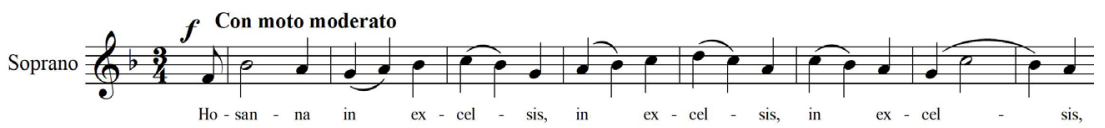

Example 3 Zdeněk Fibich, Missa brevis, op. 21, Hosanna, mm. 30-38 (soprano)

The melodic inventiveness is remarkable and creative and is enhanced with shifts in dynamics and expression of tempo. The simple but lovely melodies are proof that Fibich was a master of melody and remind us of Bukovin, a number of choral compositions (e.g. Ruhenttal and Früblingslob), the cycle of songs Šestero pisni [Six Songs] op. 12 and the cantata Jarni romance [Spring Romance] op. 23. The melodic line is diatonic, based on second or third intervals, and its progression is commonly rising, then falling. The thematic material tends to be periodical. The chromatic passages in the Credo on the words Qui propter nos homines, contrasting with the choral recitative on the words incarnatus est which are sung unisono starting on the note $\mathrm{g}$, are a rather exceptional element. In contrast, the melody of the Sanctus seems to be rather song-like, while the Benedictus is perhaps too sweet. Its triple metre and sequential progression resemble a contemporary popular music hit rather than a church chorus. (Example 3)

The identical Hosanna and Amen in both Sanctus and Benedictus have already been mentioned above. Some parts of the ordinary are united by the same motifs, for instance the incipit Domine is similar to the fugato in the Gloria.

The first three parts and Agnus are in a strict triple metre, while the remaining parts use quadruple time. 
As concerns the evaluation of the general structure of the cycle, it may be said that the compositional whole is asymmetrical. The first three parts outclass the remaining movements of the composition not only with regard to their length, which depends on the text of the individual parts, but also in terms of the quality of their elaboration. The lack of development in the latter parts is caused for instance by the repetition of entire passages of certain parts, lesser melodic ornamentation of the vocal lines, the fact that the organ part only doubles the vocal lines, as well as by the character of the melodies of the Benedictus and Dona nobis pacem which are on the brink of being kitschy.

The analysis confirms the composer's main objective: to write a short and simple composition capable of being performed without trouble by any choral ensemble so that the composition might serve for daily liturgical practice. Fibich's mass is the composition of an author who was technically skilled and acquainted with contemporary musical trends and who sensitively arranged everything that was considered traditional, well-established, and appropriate in contemporary sacred music of the Roman-Catholic rite, even if that resulted in a lack of stylistic uniformity.

By omitting orchestral accompaniment and the engagement of solo vocal parts, as well as by including elements of Renaissance vocal polyphony, Fibich strengthened the depth of the sacramental function of the composition and could associate himself with the Cyril Movement. One may state the hypothesis that had Fibich continued composing liturgical music, he would have come even closer to the 'reformed' musical styles of the second generation of Czech Cyrillian composers. This hypothesis is supported with the incipit of a Kyrie from the year 1886 composed as a cappella polyphony.

An acquaintance with the historical context may be seen in Fibich's work with Baroque polyphony: the employment of basso continuo and the arrangement of harmony in accordance with the principles of the Protestant chorale in the instrumental element. Links to Orthodox music have been found in the final plagal cadences in certain parts of the composition, as well as in the relationship between the two main keys of the entire cycle.

By contrast the prevalence of homophony, the utilization of fugato in the final sections of the ordinary, the repetition of entire passages, as well as the option for engaging the entire string orchestra ad libitum are elements following the tradition of Czech Classical-period figural music. 


\section{c) The Role of the Composition in the Context of Czech and Western European Liturgical Compositions}

Fibich's mass is comparable to the style of authors composing within the first stage of the Cyril Movement, i.e. Pavel Křižzovský, Josef Förster and František Zdeněk Skuherský. While there is only a hint of Renaissance compositional technique, their compositions evoke a pious expression; the lyrics are clearly comprehensible, and the compositions may be performed by any church ensemble.

While it is true that Fibich's approach cannot be compared to the advanced polyphonic technique and modern harmony used by authors of the second stage of the Cyril Movement, ${ }^{38}$ with regard to the utilization of Baroque elements Fibich could compete with e.g. compositions by Josef Nešvera (Missa in Honorem Sancti Gustavi op. 36, 1887). Fibich's utilization of the formal developments and principles of figural music also presaged the synthesis of twentieth-century liturgical compositions, such as Vojtěch Ríhovskýs Missa in Honorem Sancti Joanni Nepomuceni op. 92a (1890).

An interesting comparison would be Fibich's mass and the Missa Vocalis (1873) by Karel Bendl. Fibich was Bendl's successor in several artistic job positions as well as being his friend. One can assume that Fibich knew Bendl's works and could have used them as one of his models. The shared compositional features of the two composers involve a utilization of all the contemporary trends connected to the composition of liturgical music. While the melody of Bendl's mass is less distinctive, the underlay of the vocal parts is more advanced and the tonal material is more daring. Bendl's composition is based to a much greater extent on the tradition of tonal music, which may be documented with the division into segments within the individual parts of the ordinary, the application of fugato in the final passages of the individual parts, etc.

It would be unreasonable to compare Fibich's mass, which has a purely practical function and was intended for a particular kind of occasion to be performed by a choir with a lower level of interpretative skill, with ceremonial pieces by F. Liszt or A. Bruckner, who linked the romantic musical expression with the tradition of symphonic spiritual music and elements of the Cecilian Movement, or with those monumental compositions by French authors such as Gounod, Franck or Fauré. Bruckner's Mass in E Minor and Liszt's Mass of Esztergom are arranged as orchestral compositions manifesting contrapuntal mastery, a sense of both sound and expression, and Liszt's Missa Choralis involves stylized elements of Gregorian chant and Palestrina-like idioms.

${ }^{38}$ Such as Josef Cyril Sychra (for example, his Missa in Honorem Sancti Methodii with an organ accompaniment, 1885) or Josef Hruška (Missa in Honorem Sancti Laurentii 1885). 
Fibich's mass can also be related to two other compositions that were created in the same period: Antonín Dvořák's Mass in D Major "Lužanskâ" (the original 1887 version with only organ accompaniment) created for the occasion of the opening of a chapel in Lužany, and Josef Suk's Mass in B fat Major "Křečovická" (the original 1888/1889 version again only with organ accompaniment). Compared to Fibich's composition, however, these two compositions are created in a more majestic manner, which is documented with the engagement of solo vocal parts as well as a richer harmonic structure. In contrast, shared features include the respect for the practical needs of ordinary church ensembles, a link to the tradition of figural music, as well as an effort at strengthening the spiritual expression. While Suk's and Fibich's compositions are of a similar length (over twenty minutes), Dvořák's composition exceeds both aforementioned compositions both in its length and in the employed compositional techniques and their advancement. In this regard, Dvořák's mass may be part of a concert repertory rather than a composition for a church ensemble, where it may be employed only under exceptional circumstances.

\section{Zdeněk Fibich's Missa brevis in F Major op. 21 in the Context of Czech Liturgical Compositions of the 1870s-1880s}

\section{Abstract}

The Missa brevis in F Major op. 21 Hud 279 (1885) was composed by Fibich during his two-year compositional crisis. The composition was frequently performed in Bohemian and Moravian churches and remained part of their repertory up until the 1940s. The composition manifests the influence of compositional techniques of Renaissance vocal polyphony, basso continuo, the harmonization technique of the Protestant chorale, as well as elements of contemporary figural music. Apart from an analysis of the composition's style and evaluation of Fibich's relationship to liturgical music, this paper also presents the reception of the composition and reflections on it, and classifies it within the context of the liturgical repertory performed in the Czech Lands in the 1870s and 1880s. Particular attention is paid to the characteristics of two contemporary tendencies: figural music and the reformation of the Cyril (Cecilian) Movement. 


\section{Missa brevis F dur op. 21 Zdeňka Fibicha v kontextu české liturgické tvorby 70. a 80 . let 19. století}

\section{Abstrakt}

Missu brevis F dur op. 21 Hud 279 (1885) Fibich vytvořil během dvouleté tvưrčí krize. Skladba se dočkala mnoha provedení v českých a moravských chrámech a zůstala součástí jejich repertoáru až do čtyřicátých let 20. století. V kompozici nalezneme vlivy kompoziční techniky renesanční vokální polyfonie, basso continuo, techniku harmonizace protestantského chorálu, ale i prvky dobové figurální hudby. Kromě stylové analýzy a vyhodnocení vztahu Fibicha k liturgické hudbě text představuje recepci a reflexi této skladby a zařazuje ji do kontextu liturgického repertoáru uváděného v českých zemích v 70. a 80. letech 19. století. Zvláštní pozornost je věnována charakteristice dvou dobových tendencí: figurální hudby a cyrilskému (cecilskému) reformnímu hnutí.

\section{Keywords}

Zdeněk Fibich; Missa brevis in F Major, liturgical music; Cecilian Movement; Cyril Movement; figural music

\section{Klíčová slova}

Zdeněk Fibich; Missa brevis F dur; liturgická hudba; cecilská reforma; cyrilismus; figurální hudba

Eva Vičarová

Katedra muzikologie FF UP Olomouc

eva.vicarova@upol.cz 